\title{
PENGARUH LATIHAN LOMPAT GAWANG DAN LATIHAN LOMPAT SAMPING TERHADAP KEMAMPUAN HEADING BOLA PADA PERMAINAN SEPAKBOLA DITINJAU DARI DAYA LEDAK OTOT TUNGKAI
}

\author{
Palmizal $^{1}$, Nurkadri $^{2}$, Budiman Agung Pratama $^{3}$
}

Keywords :

Training; Jump Hurdles; Jump Side; Ball Heading; Leg

Muscle Explosion Power

\author{
Corespondensi Author \\ ${ }^{1}$ Universitas Negeri Jambi, \\ palmizal@unja.ac.id \\ ${ }^{2}$ Universitas Negeri Medan, \\ nurkadri@unimed.ac.id \\ ${ }^{3}$ Universitas Nusantara PGRI Kediri, \\ agung10@unpkediri.ac.id
}

\section{Article History}

Received: Mei 2019;

Reviewed: Mei 2019;

Accepted: Juni 2019;

Published: Juni 2019

\begin{abstract}
This research is a field experimental study with a $2 \times 2$ factorial design. The population is all students of the Faculty of Sport Science, Jambi State University with SportsTraining Education samples with a sampling technique is a proportional sampling of 40 people. The data analysis technique used is Analysis of Variance (ANAVA) at a significant level of 95\%. By looking at the existing problems, the results obtained from the data processing shows that: there is no significant difference in effect between hurdles and side jump exercises on the ability of heading balls in football $(F o=0.939>F t=4.11)$. There is a significant difference between the power of high limb muscle explosions with low limb muscle explosiveness to the ability of heading balls in football $\left(F_{O}=17,976>F t=4.11\right)$. For athletes who have high leg muscle explosive power, there is a significant difference in effect between goal jump training and side lomato training on ball heading abilities in football (to $=6.034>t t=$ 1.73). For athletes who have low leg muscle explosive power, there is a significant difference in effect between hurdles and side jump exercises on heading ball abilities in football (to $=$ $12,357>t t=1.73)$.
\end{abstract}

\section{ABSTRAK}

Penelitian ini adalah penelitian eksperimen lapangan dengan rancangan faktorial $2 \times 2$. Populasi adalah seluruh mahasiswa Fakultas Ilmu Keolahragaan Universitas Negeri Jambi dengan sampel Pendidikan Kepelatihan Olahraga dengan teknik pengambilan sampel adalah proporsive sampling berjumlah 40 orang. Teknik analisis data yang digunakan adalah Analisis Varians (ANAVA) pada taraf signifikan 95\%. Dengan melihat permasalahan yang ada, dengan hasil nilai yang diperoleh dari pengolahan data menunjukkan bahwa: tidak ada perbedaan pengaruh yang signifikan antara latihan lompat gawang dan latihan lompat samping terhadap kemampuan heading bola pada permainan sepakbola $\left(F_{0}=0,939>F t=4,11\right)$. Ada perbedaan yang signifikan antara daya ledak otot tungkai tinggi dengan daya ledak otot tungkai rendah terhadap kemampuan heading bola pada permainan sepakbola $\left(F_{0}=\right.$ 


\begin{abstract}
17,976 > Ft $=4,11$ ). Bagi atlet yang memiliki daya ledak otot tungkai tinggi, ada perbedaan pengaruh yang signifikan antara latihan lompat gawang dan latihan lomat samping terhadap kemampuan heading bola pada permainan sepakbola (to = $6,034>t t=1,73)$. Bagi atlet yang memiliki daya ledak otot tungkai rendah, ada perbedaan pengaruh yang signifikan antara latihan lompat gawang dan latihan lompat samping terhadap kemampuan heading bola pada permainan sepakbola $(t o=12,357>t t=1,73)$.
\end{abstract}

\section{PENDAHULUAN}

Perkembangan olahraga sepakbola telah mengalami kemajuan, baik partisipasi dari segala lapisan masyarakat maupun penampilan para olahragwan. Keberhasilan ini tidak terlepas dari usaha atau daya upaya yang berkesinambungan dari pemerintah untuk memasyarakatkan olahraga dan mengolahragakan masyarakat. Permainan sepakbola sebagai salah satu cabang olahraga yang sangat populer dan digemari oleh masyarakat dan telah menduduki posisi tertinggi dalam imajinasi dari segala lapisan masyarakat, sehingga dengan mudah dapat digunakan sebagai alat komunikasi oleh masyarakat yang memiliki persamaan kegiatan, akibatnya dalam masyarakat selalu hadir berbagai kelompok persepakbolaan yang masih perlu pembinaan dan pelatihan yang lebih mengacu pada landasan ilmiah untuk mencapai hasil yang optimal. Penerapan ilmu dan teknologi dapat membantu dalam peningkatan prestasi sepakbola, salah satu usaha yang harus dilakukan adalah melakukan penelitian terhadap faktor-faktor yang dapat menunjang peningkatan prestasi sepakbola. Dalam pembinaan dan pelatihan sepakbola masih saja dijumpai latihan yang mengacu pada teknis permainan misalnya langsung bermain, tanpa harus memperhatikan latihanlatihan khusus yang dapat menunjang teknikteknik permainan sepakbola seperti latihan untuk meningkatkan heading atau menyundul bola. Dalam menganalisa dan melakukan aktivitas olahraga tidak terlepas dari pembahasan kemampuan fisik. Untuk melakukan suatu gerakan olahraga unsurunsur fisik merupakan pelaku utama dari kegiatan tersebut. Oleh karena itu kemampuan fisik merupakan salah satu faktor yang sangat menentukan untuk mencapai suatu prestasi. Dalam permainan sepakbola hampir semua anggota tubuh bereaksi dan bekerja, namun unsur-unsur yang paling dominan adalah kaki disamping itu kepala.

Kemampuan heading bola dalam permainan sepakbola merupakan serangkaian gerakan yang dilakukan dengan melibatkan unsur fisik seperti kekuatan otot leher, kecepatan untuk bereaksi, daya ledak tungkai dalam meraih bola dan kelentukan tubuh pada saat melakukan heading. Otot-otot yang kuat akan dapat membuat kerja fisik lebih efesien, dengan penguasaan teknik yang sempurna ditunjang oleh kemampuan fisik, maka dalam proses heading bola dapat menggunakan tenaga minimal dan dicapai hasil maksimal. Dalam permainan sepakbola seorang pemain tidak akan mampu mengarahkan tenaga yang maksimal dalam menarik kepala untuk mengheading bola tanpa didukung oleh kekuatan otot-otot leher dan kelentukan tubuh. Dalam melakukan heading bola, selain unsur fisik yang merupakan faktor utama bagi keberhasilan, juga tak kalah pentingnya adalah unsur teknik dalam melakukan heading tersebut. Dengan memperhatikan hal tersebut di atas, tinggal bagaimana melatih otot leher dengan kuat, sehingga pada akhirnya dapat memperoleh hasil heading yang keras dan akurat. Untuk menghasilkan heading bola yang keras dan akurat disamping membutuhkan kekuatan otot leher juga kemampuan otot tungkai untuk melakukan lompatan dalam meraih bola, maka perlu latihan yang secara spesifik dapat memberikan kontribusi terhadap peningkatan daya ledak otot tungkai dalam melakukan heading bola. Mengingat sangat pentingnya kemampuan tersebut, dengan heading bola pemain dapat memasukkan bola. Sebab semua bola yang masuk terjadi akibat dari kaki akan tetapi kadang kala kepala. Hal yang sangat mendasar tentang pemain yang ada pada pemain di kabupaten Bantaeng adalah kemampuan otot tungkai untuk melakukan loncatan dalam 


\section{Volume 11 Nomor 2, Juni 2019}

meraih bola, sehingga kadang kala dalam perebutan bola di udara selalu ketinggalan, sehingga lawan dapat menguasai bola. Untuk pengembangan daya ledak otot tungkai dalam menunjang kemampuan heading bola dalam permainan sepakbola, maka penulis memilih latihan yang mampu untuk memberikan kontribusi terhadap peningkatan teknik tersebut, disamping daya ledak tungkai sebagai penunjang. Latihan yang dimaksud adalah latihan lompat gawang dan latihan lompat samping.

Dari kedua bentuk latihan ini, tentunya memiliki persepsi atau tujuan yang sama yaitu untuk meningkatkan kemampuan atau kerja otot tungkai untuk lebih kuat. Namun dalam pelaksanaannya tentunya berbeda, satu hal hanya dilakukan pada posisi melompat ke depan (lompat gawang) dan satunya lompat kesamping dengan posisi badan menyamping (lompat samping). Kedua bentuk latihan disaat melakukan lompatan kepala melakukan pergerakan mengheading. Jadi disamping melakukan lompatan melalui hambatan berupa gawang yang memiliki tinggi 50 centimeter dengan jumlah 4 buah, juga diharuskan untuk melakukan pergerakan heading bayangan atau tanpa bola. Kedua bentuk latihan ini memiliki kelebihan dan kekurangan masing-masing.

Heading bola merupakan salah satu dari beberapa teknik yang ada pada permainan sepakbola, yang harus memenuhi ketentuan peraturan permainan untuk dimanfaatkan dalam bermain sepakbola. Dalam situasi bermain sepakbola, bola tidak selamanya hanya dimainkan dengan kaki tetapi juga menggunakan kepala apabila arah datangnya bola di atas jangkauan kaki. Bola disundul dengan menggunakan kepala dengan tujuan untuk : (1) Memasukkan bola ke gawang, (2) Mematahkan serangan lawan, (3) Mengoper atau memberi umpan, dan (4) Mengontrol bola. Gerakan heading atau menyundul bola dapat dilakukan dalam berbagai posisi, seperti; posisi berdiri, posisi sambil berlari dan posisi melompat. Heading dalam posisi berdiri dilakukan apabila arah datangnya bola tidak melambung tinggi tetapi arah bola tepat kepala. Selain dari itu arah datangnya bola melambung tinggi dan pemain tetap menunggu sampai turunnya bola tepat di kepala untuk disundul. Dengan posisi ini pemain dapat menyundul bola ke atas, ke depan, ke belakang dan ke samping. Heading bola dalam posisi berdiri dilakukan apabila bola yang datang melambung tinggi atau mendatar searah kepala dan jauh dari jangkauan. Pemain harus berlari menuju arah bola dan melakukan heading atau sundulan. Heading bola dalam posisi berlari, $p$ emain dapat mengheading bola pada arah yang sama seperti posisi berdiri. Heading bola sambil melompat dilakukan apabila bola yang datang melambung tinggi dan pemain harus cepat merebut bola tersebut sebelum direbut oleh lawan. Selain dari itu bola yang datangnya melambung tinggi di depan gawang, maka pemain penyerang maupun pertahanan merebut bola tersebut dengan mengheading atau menyundul sambil melompat. Dapat juga mengheading bola sambil berlari dan melompat dengan kemungkinan pada saat berlari menuju arah bola sambil melompat dan menyundul.

Daya ledak adalah kemampuan otot untuk mengatasi tahanan dan kontraksi yang sangat cepat, jadi kekuatan dan kecepatan haruslah ditingkatkan menjadi apa yang disebut daya ledak. Harsono (1988:199) mengemukakan bahwa: "Power lebih diperlukan dalam semua cabang olahraga, karena di dalam power terdapat kekuatan dan kecepatan". Pengembangan tenaga eksplosive power dalam eksperimen ini dilakukan dengan latihan kombinasi kekuatan dan kecepatan. Seorang dapat dikatakan bertenaga penuh (power), menurut Abd. Kadir Ateng (1992:140) apabila memiliki: (1) Tingkat kekuatan otot yang tinggi, (2) Tingkat kecepatan yang tinggi, dan (3) Tingkat kemampuan yang tinggi dalam mengintegrasikan kecepatan dan kekuatan otot. Sehubungan dengan itu dikemukakan pula oleh Harsono (1988:199) bahwa: "Power adalah hasil dari force Velocity di mana force adalah sepadan (equivalent) dengan strnght dan velocity dengan speed". Sedangkan Harre. D (1982:108) mengemukakan bahwa: "Power is the ability of an athlet to overcome resistences by a high speed af contraction". Berdasarkan dengan uraian tentang power, dapat disimpulkan bahwa power atau daya ledak adalah kemampuan otot atau sekelompok otot dalam melakukan kerja secara aks plosif, power dipengaruhi oleh kekuatan dan kecepatan kontraksi otot. Ditinjau dari kegunaannya di mana kekuatan berperan utama dalam gerakannya. Kekuatan dan kecepatan 


\section{e-ISSN: 2657-0703 dan p-ISSN: 2085-5389}

kontraksi otot pada bagian tungkai sangat menentukan jarak frekuensi langkah.

Latihan merupakan faktor yang sangat penting dalam proses kepelatihan untuk mencapai prestasi maksimal dalam suatu cabang olahraga. Suharno HP. (1993:5) mengemukakan bahwa : Latihan adalah suatu proses penyempurnaan secara sadar untuk mencapai mutu prestasi maksimal dengan diberi beban fisik, teknik, taktik dan mental yang teratur, terarah, meningkat, bertahap dan berulang waktunya. Berdasarkan pendapat tersebut, dapat dikemukakan bahwa dengan berlatih secara sistematis dengan pengulangan secara teratur, maka fungsi mekanisme otot semakin baik, gerakangerakan yang semula sukar untuk dilakukan, lama kelamaan akan menjadi gerakan yang otomatis dan refleksif. Dengan demikian latihan merupakan cara kerja yang sistematis dan berfungsi sebagai alat dengan prosedur belajar atau berlatih untuk meningkatkan prestasi atlet. Dalam penelitian ini, bentuk latihan yang diterapkan untuk meningkatkan kekuatan, kecepatan, daya ledak dan kelentukan sehingga dapat melakukan heading bola dalam permainan sepakbola secara terampil adalah:

Pada dasarnya latihan lompat gawang adalah salah satu bentuk latihan beban yang apabila diatur secara terprogram akan meningkatkan kemampuan fisik seseorang. Pada latihan ini, kondisi fisik yang paling menonjol pengembangannya adalah daya ledak atau power. Power adalah kombinasi antar kekuatan dan kecepatan kontraksi otot. Latihan lompat gawang bertujuan untuk meningkatkan kinerja otot tungkai. Pengertian pada latihan lompat gawang adalah kemampuan untuk melakukan suatu lompatan yang dilakukan dengan menggunakan alat bantu berupa gawang yang berukuran tinggi 50 centimeter dengan panjang palang 100 centimeter ( 1 meter ). Jumlah gawang yang digunakan sebanyak empat, jarak antara tiap gawang 1 meter. Pelaksanaan latihan lompat gawang yaitu dengan melompat ke atas melewati gawang, kedua kaki melakukan penolakan ke atas melewati rintangan, kedua kaki melakukan penolakan secara bersamasama dan mendarat dibelakang gawang dan selanjutnya melakukan lompatan ke gawang berikutnya sampai selesai.

Latihan lompat samping hampir sama dengan latihan lompat gawang, dimana menggunakan berupa alat bantu berupa gawang yang memiliki ukuran yang sama dan jumlah gawang yang digunakan sama pula. Namun dalam pelaksanaan latihan lompat samping dilakukan dengan badan atau pandangan tetap menghadap ke depan, tapi arah lompatan ke samping. Kedua bentuk latihan ini memiliki tujuan yang sama yaitu untuk mengembangkan kerja otot dalam mencapai kemampuan kondisi fisik berupa daya ledak pada otot tungkai. Sehingga dari sistem pelaksanaannya dapat mengembangkan otot-otot, seperti ; musculus rectus femoris, musculus vastus medialis, musculus gastornemius, musculus soleus, musculus semitendinosus, musculus semibronosus, dan musculus abdominialis.

\section{METODE}

Metode yang digunakan dalam penelitian ini adalah metode eksperimen lapangan. Adapun variabel penelitian yang ingin diteliti dalam penelitian ini terdiri atas: (1) variabel bebas terdiri latihan lompat gawang dan latihan lompat samping, (2) variabel terikat yaitu heading bola, dan (3) variabel kontrol yaitu daya ledak otot tungkai. Desain penelitian adalah rancangan suatu penelitian untuk mencapai tujuan dalam penelitian yang dirumuskan. Desain penelitian yang digunakan adalah : "Desain faktorial 2 x 2". Untuk lebih jelasnya sebagai berikut :

\begin{tabular}{|c|c|c|}
\hline $\begin{array}{c}\text { Latihan } \\
\text { Daya Ledak } \\
\text { Otot Tungkai }\end{array}$ & $\begin{array}{c}\text { Lompat Gawang } \\
(\mathbf{A} 1)\end{array}$ & $\begin{array}{c}\text { Lompat Samping } \\
\text { ( A2 ) }\end{array}$ \\
\cline { 1 - 3 } $\begin{array}{c}\text { Tinggi } \\
\text { (B1) }\end{array}$ & $(A 1 B 1)$ & $(A 2 B 1)$ \\
\cline { 1 - 2 } $\begin{array}{c}\text { Rendah } \\
\text { (B2) }\end{array}$ & $(A 1 B 2)$ & $(A 2 B 2)$ \\
\multicolumn{3}{|c|}{$\begin{array}{c}\text { Gambar 1. } \\
\text { Desain faktorial 2x2 }\end{array}$}
\end{tabular}




\section{Volume 11 Nomor 2, Juni 2019}

Populasi dalam penelitian ini adalah seluruh mahasiswa Fakultas Ilmu Keolahragaan Universitas Negeri Jambi. Beranjak dari itu yang menjadi sampel dalam penelitian ini adalah mahasiswa Program Studi Pendidikan Kepelatihan Olahraga sebanyak 40 orang. Setelah tes secara keseluruhan telah dilaksanakan, maka data penelitian berupa tes daya ledak otot tungkai dan tes heading bola dalam permainan sepakbola dari kelompok sampel dianalisis secara statistik melalui

Tabel 1.

Hasil data deskriptif kemampuan heading bola pada permainan sepakbola

\begin{tabular}{|c|c|c|}
\hline$\underbrace{\text { Latihan }}_{\begin{array}{l}\text { Daya ledak } \\
\text { Otot Tungkai }\end{array}}$ & $\begin{array}{c}\text { Lompat Gawang } \\
\text { ( A1 ) }\end{array}$ & $\begin{array}{c}\text { Lompat Samping } \\
\text { ( A2 ) }\end{array}$ \\
\hline $\begin{array}{l}\text { Tinggi } \\
(\mathrm{B} 1)\end{array}$ & $\begin{array}{l}\mathrm{N}: 10 \\
\sum \mathrm{X}: 9078 \\
\sum \mathrm{X}^{2}: 8250418 \\
\mathrm{X}: 907,8 \\
\mathrm{Sd}: 32,33436424\end{array}$ & $\begin{array}{l}\mathrm{N}: 10 \\
\sum \mathrm{X}: 8829 \\
\sum \mathrm{X}^{2}: 7788513 \\
\mathrm{X}: 882,9 \\
\mathrm{Sd}: 22,08292452\end{array}$ \\
\hline $\begin{array}{c}\text { Rendah } \\
\text { ( B2 ) }\end{array}$ & $\begin{array}{l}\mathrm{N}: 10 \\
\sum \mathrm{X}: 8631 \\
\sum \mathrm{X}^{2}: 7419585 \\
\mathrm{X}: 863,1 \\
\mathrm{Sd}: 11,58591098\end{array}$ & $\begin{array}{l}\mathrm{N}: 10 \\
\sum \mathrm{X}: 8734 \\
\sum \mathrm{X}^{2}: 7629406 \\
\mathrm{X}:: 873,4 \\
\mathrm{Sd} \quad: 11,20714058\end{array}$ \\
\hline
\end{tabular}

\section{Pengujian persyaratan analisis}

Data penelitian ini diolah dengan menggunakan Analisis Varians (ANAVA). Namun sebelum data dianalisis untuk pengujian hipotesis, maka terlebih dahulu dilakukan uji persyaratan yaitu uji normalitas dan homogenitas. teknik deskriptif dan infrensial dengan dilanjutkan pada analisis varians (ANAVA) pada taraf signifikan $95 \%$.

\section{HASIL DAN PEMBAHASAN}

Gambaran umum dari hasil penelitian dikemukakan ringkasan hasil penelitian dalam data deskriptif pada kemampuan heading bola pada permainan sepakbola sebagai berikut :
1. Uji Normalitas sampel

Uji normalitas menggunakan uji Lilifors dengan taraf signifikan $\alpha=0,05$. perhitungan lengkap uji normalitas dapat dilihat pada lampiran. Untuk rangkuman hasil pengujian dapat dilihat pada tabel berikut :

Tabel 2.

Hasil uji normalitas sampel

\begin{tabular}{|c|c|c|c|c|}
\hline Kelompok & $\mathbf{N}$ & Lo & $\mathbf{L t}$ & Kesimpulan \\
\hline 1 & 30 & 0,162 & 0,190 & Normal \\
2 & 30 & 0,186 & 0,190 & Normal \\
3 & 30 & 0,175 & 0,190 & Normal \\
4 & 30 & 0,179 & 0,190 & Normal \\
5 & 15 & 0,152 & 0,258 & Normal \\
6 & 15 & 0,236 & 0,258 & Normal \\
7 & 15 & 0,152 & 0,258 & Normal \\
8 & 15 & 0,100 & 0,258 & Normal \\
\hline
\end{tabular}

Keterangan :

Kelompok 1 : Kelompok latihan lompat gawang

Kelompok 2 : Kelompok latihan lompat samping

Kelompok 3 : Kelompok daya ledak otot tungkai tinggi 


\section{e-ISSN: 2657-0703 dan p-ISSN: 2085-5389}

Kelompok4 : Kelompok daya ledak otot tungkai rendah

Kelompok 5 : Kelompok latihan lompat gawang untuk daya ledak otot tungkai tinggi

Kelompok 6 : Kelompok latihan lompat samping untuk daya ledak otot tungkai tinggi

Kelompok 7 : Kelompok latihan lompat gawang untuk daya ledak otot tungkai rendah

Kelompok 8 : Kelompok latihan lompat samping untuk daya ledak otot tungkai rendah

Lo

: Harga lilifors observasi

Lt : Harga lilifors tabel

Berdasarkan tabel di atas, menunjukkan bahwa L (lilifors) observasi untuk semua kelompok sampel yang diperoleh semuanya lebih kecil daripada nilai L (lilifors) tabel pada taraf signifikan $\alpha=0,05$. dengan demikian dapat disimpulkan bahwa sampel berasal dari populasi yang berdistribusi normal.

2. Uji homogenitas sampel

Hasil perhitungan uji homogenitas yang diperoleh pada lampiran, dirangkum pada tabel berikut ;

Tabel 3

Hasil uji homogenitas sampel

\begin{tabular}{|c|c|c|c|}
\hline $\begin{array}{c}\text { Kelompok yang } \\
\text { dibandingkan }\end{array}$ & F observasi & F tabel & Kesimpulan \\
\hline A1 : A2 & 1,61 & 2,15 & Homogen \\
\hline B1 : B2 & 1,54 & 2,15 & Homogen \\
\hline A1B1 : A2B1 & 1,01 & 3,18 & Homogen \\
\hline A1B2 : A2B2 & 1,37 & 3,18 & Homogen \\
\hline
\end{tabular}

Oleh karena semua F observasi lebih kecil dari pada $F$ tabel pada taraf signifikan $\alpha=0,05$. maka dapat disimpulkan bahwa semua kelompok adalah kelompok yang homogen.

Dengan demikian dari hasil pengujian persyaratan ini, semua kelompok normal dan homogen tentunya dapat dilanjutkan pengujian hipotesis.

Tabel 4

Hasil analisis varians

\begin{tabular}{|c|c|c|c|c|c|}
\hline $\begin{array}{c}\text { Sumber } \\
\text { Variasi }\end{array}$ & $\mathbf{d b}$ & $\mathbf{D K}$ & $\mathbf{M K}$ & $\mathbf{F o}$ & $\mathbf{F t}_{\mathbf{0}, \mathbf{0 5}}$ \\
\hline $\begin{array}{c}\text { Metode (A) } \\
\text { (antar) }\end{array}$ & 1 & 409,6 & 409,6 & $\mathbf{0 , 9 3 9}$ & 4,11 \\
$\begin{array}{c}\text { Tingkatan (B) } \\
\text { (antar) }\end{array}$ & 1 & 7840 & 7840 & $\mathbf{1 7 , 9 7 6}$ & 4,11 \\
$\begin{array}{c}\text { Interaksi } \\
\text { (A) x (B) }\end{array}$ & 1 & 3422,5 & 3422,5 & $\mathbf{7 , 8 4 7}$ & 4,11 \\
\hline Dalam & 37 & 16137 & 436,1351351 & - & - \\
\hline Jumlah & 40 & 27809,1 & - & - & - \\
\hline
\end{tabular}

Keterangan :

$d b=$ Derajat kebebasan

$D K=$ Jumlah kuadrat

$M K=$ Rata-rata jumlah kuadrat

$F_{0}=$ Harga Fobservasi

$F t=$ Harga F tabel

\section{Pengujian hipotesis}

Untuk menguji hipotesis guna teknik analisis varians dua jalur dan analisis t-test. Perhitungan lengkap analisis varians tersebut dapat dilihat pada lampiran sedangkan rangkuman hasil analisis dapat dilihat pada tabel berikut : 


\section{Volume 11 Nomor 2, Juni 2019}

Untuk selanjutnya akan dijelaskan tentang hasil analisis tersebut terhadap hipotesis yang diajukan sebagai berikut:

a. Ada perbedaan pengaruh antara latihan lompat gawang dan latihan lompat samping terhadap kemampuan heading bola pada permainan sepakbola.

Berdasarkan hasil analisis varians sebagaimana dicantumkan atau digambarkan pada tabel di atas, nampak harga Fo $=0,939$ lebih kecil dari harga $F$ tabel pada taraf signifikan $(\alpha=0,05)=4,11$. Dengan demikian Ho diterima dan H1 ditolak, sehingga dapat disimpulkan bahwa secara keseluruhan, tidak terdapat perbedaan kemampuan heading bola pada permainan sepakbola yang signifikan antara latihan lompat gawang dan latihan lompat samping.

b. Ada perbedaan antara kelompok yang memiliki daya ledak otot tungkai tinggi dan kelompok yang memiliki daya ledak otot tungkai rendah terhadap kemampuan heading bola pada permainan sepakbola.
Berdasarkan hasil analisis varians sebagaimana dicantumkan atau digambarkan pada tabel di atas, nampak harga Fo $=17,976$ lebih besar dari harga $F$ tabel pada taraf signifikan $(\alpha=0,05)=4,11$. Dengan demikian Ho ditolak dan H1 diterima, sehingga dapat disimpulkan bahwa secara keseluruhan, terdapat perbedaan kemampuan heading bola pada permainan sepakbola yang signifikan antara kelompok daya ledak otot tungkai tinggi dan kelompok daya ledak otot tungkai rendah. Dan atlet yang memiliki daya ledak otot tungkai tinggi lebih baik dibandingkan dengan atlet yang memiliki daya ledak otot tungkai rendah.

Untuk pengujian hipotesis ketiga dan keempat digunakan analisis uji t-test. Perhitungan lengkap dapat dilihat pada lampiran dan hasilnya dapat dilihat pada tabel rangkuman berikut :

Tabel 5.

Rangkuman hasil analisis uji t-test

\begin{tabular}{|c|c|c|c|}
\hline Nomor & $\begin{array}{c}\text { Kelompok yang } \\
\text { dibandingkan }\end{array}$ & $\mathbf{t}$ hitung & $\mathbf{t}$ tabel \\
\hline 1 & A1B1 : A2B1 & 6,034 & 1,73 \\
2 & A1B2 : A2B2 & 12,357 & 1,73 \\
\hline
\end{tabular}

c. Bagi atlet yang memiliki daya ledak tungkai tinggi, ada perbedaan pengaruh antara latihan lompat gawang dan latihan lompat samping terhadap kemampuan heading bola pada permainan sepakbola.

Berdasarkan hasil analisis data sebagaimana digambarkan atau tercantum di atas pada tabel yang merupakan hasil perhitungan uji t-test menunjukkan bahwa ada perbedaan pengaruh kemampuan heading bola pada permainan sepakbola signifikan antara latihan lompat gawang dan latihan lompat samping pada kelompok daya ledak otot tungkai tinggi terbukti dari hasil pengolahan data yang diperoleh bahwa $\mathbf{t}_{\text {hitung }}$ $=6,034>t_{\text {tabel }}=1,73$. Dengan demikian Ho ditolak dan $\mathrm{H} 1$ diterima. Maka dapat ditarik sebuah kesimpulan bahwa pada kelompok atlet yang memiliki daya ledak otot tungkai tinggi dengan latihan lompat gawang ( $\mathrm{X}=$ 907,$8 ; \mathrm{Sd}=32,334$ ) lebih efektif dibandingkan dengan latihan lompat samping $(\mathrm{X}=39,37 ; \mathrm{Sd}=0,289)$.

d. Bagi atlet yang memiliki daya ledak tungkai rendah, ada perbedaan pengaruh antara latihan lomat gawang dan latihan lompat samping terhadap kemampuan heading bola dalam permainan sepakbola.

Berdasarkan hasil analisis data sebagaimana digambarakan atau tercantum di atas pada tabel yang merupakan hasil perhitungan uji t-test menunjukkan bahwa ada perbedaan pengaruh kemampuan heading bola pada permainan sepakbola yang signifikan antara latihan lompat gawang dan latihan lompat samping pada kelompok daya ledak otot tungkai rendah terbukti dari hasil pengolahan data yang diperoleh bahwa $t_{\text {hitung }}$ $=12,357>t_{\text {tabel }}=1,73$. Dengan demikian Ho ditolak dan H1 diterima. Maka dapat ditarik sebuah kesimpulan bahwa pada 


\section{e-ISSN: 2657-0703 dan p-ISSN: 2085-5389}

kelompok atlet yang memiliki daya ledak otot tungkai tinggi dengan latihan lompat samping ( $\mathrm{X}=863,1$; $\mathrm{Sd}=11,586$ ) lebih efektif dibandingkan dengan latihan lompat gawang $(\mathrm{X}=878,4 ; \mathrm{Sd}=11,207)$.

\section{Pembahasan}

Dalam penelitian ini, tes daya ledak tungkai dijadikan dasar untuk membagi kelompok-kelompok yang mempunyai daya ledak otot tungkai tinggi (B1) dan daya ledak tungkai rendah (B2). Penelitian ini juga membedakan kemampuan heading bola pada permainan sepakbola antara kelompok yang dijadikan persel yaitu kelompok daya ledak otot tungkai tinggi untuk latihan lompat gawang (A1B1), kelompok daya ledak otot tungkai tinggi untuk latihan lompat samping (A2B1), kelompok daya ledak otot rendah untuk latihan lompat gawang (A1B2), dan kelompok daya ledak otot tungkai rendah untuk latihan lompat samping (A2B2). Penelitian ini tidak melihat pengaruh latihan sebelum dan sesudah latihan, tetapi penelitian ini melihat seberapa jauh perbedaan pengaruh kedua bentuk latihan yaitu latihan lompat gawang (A1) dan latihan lompat samping (A2) serta dengan kelompok yang dibagi persel, dalam hal ini data yang dianalisis adalah data tes akhir.

Hasil pengujian hipotesis pertama : tidak ada perbedaan pengaruh yang signifikan antara latihan lompat gawang dan latihan lompat samping terhadap kemampuan heading bola pada permainan sepakbola. Terbukti dari hasil pengujian nilai $\mathrm{F}$ observasi lebih kecil dibanding dengan nilai $\mathrm{F}$ tabel. Kedua bentuk latihan tersebut merupakan bentuk latihan yang mengarah pada peningkatan kemampuan fisik dalam melakukan heading bola, disamping itu baik latihan lompat gawang maupun latihan lompat samping juga memiliki kontraksi otot yang sama dalam hal ini untuk meningkatkan kerja otot dalam mencapai atau menjangkau bola yang diatas. Dalam permainan sepakbola, pemain kadang kala memperebutkan bola yang ada diudara yang selanjutnya melakukan heading atau mengumpan bola dengan kepala, sehingga bagi pemain yang kurang memiliki kemampuan fisik daya ledak otot tungkai maka lompatan untuk meraih bola tidak akan tercapai. Olehnya itu kedua bentuk latihan tersebut, dengan tujuan kedua bentuk latihan maka disimpulkan tidak memiliki perbedaan dalam kemampuan heading, sebab lebih banyak mengarhkan pada peningkatan unsur fisik daya ledak.

Pengujian hipotesis kedua menunjukkan bahwa ada perbedaan yang signifikan antara kelompok daya ledak otot tungkai tinggi dan kelompok daya ledak otot tungkai rendah terhadap kemampuan heading bola pada permainan sepakbola. Tentunya bahwa kelompok atlet yang memiliki daya ledak otot tungkai tinggi lebih produktif dibandingkan kelompok daya ledak tungkai rendah. Dalam permainan sepakbola khususnya pada teknik heading bola, seorang pemain diharuskan dan dituntut untuk mampu menjangkau bola yang biasa diperebutkan baik bola di atas maupun di depan gawang, sebab tidak selamanya serangan yang dilakukan berasal dari hasil dari kaki ke kaki akan tetapi biasanya serangan yang dilakukan secara kepala apalagi untuk memasukan bola ke gawang. Sehingga bagi mereka atau pemain yang kurang memiliki kemampuan fisik seperti daya ledak yang baik maka hasil heading yang dimilikinya tidak optimal.

Pengujian hipotesis ketiga menunjukan bahwa pada kelompok daya ledak otot tungkai tinggi ada perbedaan yang signifikan antara latihan lompat gawang dan latihan lompat samping terhadap kemampuan heading bola pada permainan sepakbola. Dari hasil analisis data yang diperoleh ternyata latihan lompat gawang memiliki kemampuan yang lebih baik dari latihan lompat samping. Untuk melakukan heading yang lebih keras dengan memperebutkan bola di udara serta lebih mengarah, adalah dengan posisi kepala lebih terarah ke depan di bandingkan mengheading bola dari samping, sehingga bagi mereka yang memiliki daya ledak otot tungkai tinggi dengan dilatih dengan kedua bentuk latihan tersebut, maka latihan lompat gawang lebih efektif sebab pada pelaksanaanya melompat ke depan.

Pengujian hipotesis keempat menunjukkan bahwa untuk kelompok daya ledak otot tungkai rendah ada perbedaan pengaruh yang signifikan antara latihan lompat gawang dan latihan lompat samping. Dari hasil analisis data diperoleh bahwa nilai observasi lebih besar dari nilai tabel, sehingga disimpulkan bahwa kedua latihan ini jika melihat dari segi daya ledak otot tungkai rendah dapat memberikan kontribusi. Kelompok yang 


\section{Volume 11 Nomor 2, Juni 2019}

memiliki daya ledak tungkai rendah dengan latihan lompat samping lebih baik dalam meningkatkan kemampuan heading bola pada permainan sepakbola, dibandingkan dengan kelompok daya ledak otot tungkai rendah untuk latihan lompat gawang.

Dari hasil pengujian keempat hipotesis tersebut, dapat disimpulkan bahwa seorang pemain sepakbola harus dituntut untuk memiliki daya ledak otot tungkai yang baik (tinggi) sebagai salah satu faktor yang menjamin dalam pencapaian hasil optimal. Disamping itu bahwa hasil penelitian ini menunjukkan bahwa hipotesis yang diajukan ternyata memberikan kontribusi yang positif dalam mengembangkan kemampuan teknik dasar yang ada dalam permainan sepakbola seperti dalam melakukan heading bola.

\section{SIMPULAN DAN SARAN}

Setelah masalah yang telah dirumuskan dan hipotesis yang diajukan serta ditujang dari hasil yang telah dicapai dari pengolahan data statistik maka dapat disimpulkan bahwa

1. Tidak ada perbedaan pengaruh yang signifikan antara latihan lompat gawang dan latihan lompat samping terhadap kemampuan heading bola pada permainan sepakbola.

2. Ada perbedaan yang signifikan daya ledak otot tungkai tinggi dan daya ledak otot tungkai rendah terhadap kemampuan heading bola pada permainan sepakbola. Dan daya ledak otot tungkai tinggi lebih baik dibandingkan dengan daya ledak otot tungkai rendah.

3. Ada perbedaan pengaruh yang signifikan antara latihan lompat gawang dan latihan lompat samping terhadap kemampuan heading bola pada permainan sepakbola ditinjau dari daya ledak otot tungkai tinggi. Dan latihan lompat gawang lebih baik bila ditinjau dari daya ledak otot tungkai tinggi dibandingkan dengan latihan lompat samping.

4. Ada perbedaan pengaruh yang signifikan antara latihan lompat gawang dan latihan lompat samping terhadap kemampuan heading bola pada permainan sepakbola ditinjau dari daya ledak otot tungkai rendah. Dan latihan lompat samping lebih baik bila ditinjau dari daya ledak otot tungkai rendah dibandingkan dengan latihan lompat gawang.

Kesimpulan yang dirangkum, maka dapat diberikan suatu saran-saran sebagai berikut :

1. Bagi pelatih bahwa untuk melatih khusus, perlu lebih mengarah pada teknik dasar dan fisik dalam permainan sepakbola, kedua bentuk latihan yaitu latihan lompat gawang dan latihan lompat samping dapat diprogramkan bagi atlet atau pemain pemula yang kurang memiliki unsur daya ledak otot tungkai.

2. Bagi pelatih diharuskan memperhatikan atlet atau pemain yang dibina atau dilatih agar daya ledak otot tungkai dijadikan faktor penunjang dalam memilih atlet sepakbola.

3. Agar hasil penelitian ini dapat dilanjutkan pada penelitian-penelitian selanjutnya walaupun dengan cabang olahraga lain dan dengan kedua bentuk latihan tersebut.

\section{DAFTAR RUJUKAN}

Ateng, Abdul Kadir. 1992. Asas dan landasan pendidikan jasmani. Jakarta : Departemen Pendidikan dan Kebudayaan Dirjen Pendidikan Tinggi.

Bompa. 1983. Theory and methodology of training the key to athletic performance. Iowa Kendall/Hunt Publishing Company.

Dwijonowinoto Kasiyo, 1993. Dasar-Dasar Ilmiah Kepelatihan. IKIP : Semarang.

Haddade, Ilyas dan Tola, Ismail. 1991. Penuntun mengajar dan melatih sepakbola. Ujung Pandang : FPOK IKIP.

Harsono, 1988. Coaching dan aspek-aspek psikologi dalam coaching. Jakarta : Departemen Pendidikan dan Kebudayaa Direktorat Jenderal Pendidikan Tinggi.

Herre. D, 1982. Priniciple of Sport Training Inducation to Theory and Metode of Training Sport. Verlag Berham.

HP. Suharno, 1993. Metodologi pelatihan. Jakarta : KONI Pusat

Jansen C.R, 1983. Apllied Kinesiologi Biomekanika. New york Hill Company.

Joseph A. Luxbacher. 1997. Sepakbola; langkah-langkah menuju sukses. Jakarta : PT. Raja Grafindo Persada. (diahli bahasa oleh Agusta Wibawa).

Kosasih, Engkos. 1991. Olahraga teknik dan program latihan. Jakarta: Penerbit Akademik Persindo. 
Muchtar, Remmy. 1992. Olahraga pilihan sepakbola. Jakarta: Departemen Pendidikan Dan Kebudayaan Direktorat Jenderal Pendidikan Tinggi PPTK.

Pasau, M. Anwar. 1993. Kesegaran jasmani, latihan dan usia. Ujung Pandang : Makalah pada seminar kesegaran jasmani Nasional.

Paul Uram, 1986. Latihan Peregangan untuk Pelatih Guru Olahraga Mahasiswa FPOK dan Atlet. Jakarta : Penerbit Akademika Presindo.

Sajoto, Moch. 1988. Pembinaan kondisi fisik dalam olahraga. Semarang: FPOK IKIP.

Samursarjono Sadoso, 1986. Pengetahun Praktis Kesehatan Dalam Olahraga. Jakarta

Surahman, Winarno. 1982. Pengantar penelitian ilmiah dasar; metode dan teknik. Bandung : PT. Tarsito. 